\title{
Double SiC Oxidation Protective Coating on C/C Composites Prepared by Spark Plasma Sintering
}

\section{Xianghong Zhang1,2*, Changhu Yu1 ${ }^{1}$, Lina Qiao', Beilong Zhao¹, Hao Huang3, Hongxia Song1, Xiaochen Sheng ${ }^{2}$}

${ }^{1}$ Hebei Vocational \& Technical College of Building Materials, Qinhuangdao, China

${ }^{2}$ Key Laboratory of Inorganic Coating Materials, Chinese Academy of Sciences, Shanghai, China

${ }^{3}$ State Key Laboratory of Metastable Materials Science \& Technology, Yanshan University, Qinhuangdao, China

Email: *hanjie110@163.com

How to cite this paper: Zhang X.H., Yu, C.H., Qiao, L.N., Zhao, B.L., Huang, H., Song, H.X. and Sheng, X.C. (2017) Double $\mathrm{SiC}$ Oxidation Protective Coating on $\mathrm{C} / \mathrm{C}$ Composites Prepared by Spark Plasma Sintering. Journal of Minerals and Materials Characterization and Engineering, 5, 374-384.

https://doi.org/10.4236/jmmce.2017.56031

Received: October 19, 2017

Accepted: November 19, 2017

Published: November 22, 2017

Copyright $\odot 2017$ by authors and Scientific Research Publishing Inc. This work is licensed under the Creative Commons Attribution International License (CC BY 4.0).

http://creativecommons.org/licenses/by/4.0/

\begin{abstract}
Easy oxidation of carbon limits applications of carbon-carbon composites in an oxygen-containing environment. In this study, a two-layer SiC coating was prepared on carbon-carbon composites by a Spark plasma sintering technology at $1350^{\circ} \mathrm{C}$ for $1 \mathrm{~min}$. The coating was mainly composed of $\beta$-SiC and $\mathrm{Si}$ and well bonded with the substrate. The double SiC coating could effectively protect the $\mathrm{C} / \mathrm{C}$ composites from oxidation at $1600^{\circ} \mathrm{C}$ for $120 \mathrm{~h}$, and the corresponding weight loss was only $2.62 \%$.
\end{abstract}

\section{Keywords \\ Carbon-Carbon Composites, Spark Plasma Sintering, Anti-Oxidation, Coating}

\section{Introduction}

Carbon/carbon (C/C) composites are promising materials used in aircraft and aerospace fields due to their excellent properties, such as high temperature strength, high thermal conductivity, low thermal expansion coefficient, good thermal shock and ablation resistance [1]. However, the oxidation of $\mathrm{C} / \mathrm{C}$ composites above $723 \mathrm{~K}$ limits their applications in an oxygen-containing environment [2] [3].

A silicon carbide $(\mathrm{SiC})$ coating, which possesses an excellent oxidation resistance and good compatibility with $\mathrm{C} / \mathrm{C}$ substrates, has attracted extensive attention [4] [5] [6]. But, due to thermal expansion mismatch between $\mathrm{SiC}$ and $\mathrm{C} / \mathrm{C}$ 
composites, cracks are easily formed in the $\mathrm{SiC}$ coating, which could offer the path for oxygen to diffuse into the composites. Consequently, various multilayer coatings are explored, such as $\mathrm{SiC} / \mathrm{SiC}$ [7] [8], mullite/SiC [9] [10], $\mathrm{MoSi}_{2} / \mathrm{SiC}$ [11], $\mathrm{AlPO}_{4} / \mathrm{SiC}$ [12], SiC-MoSi $-\mathrm{ZrB}_{2} / \mathrm{SiC}$ [13]. Among them, double SiC coating is considered as a good choice to protect $\mathrm{C} / \mathrm{C}$ composites from oxidation because of no thermal expansion mismatch between the outer layer and the inner layer.

Up to now, three methods, namely pack cementation, chemical vapor deposition and slurry method, are mainly used to prepare coatings on C/C composites. Among them, pack cementation, which is usually used to offer a strong interface bonding between $\mathrm{SiC}$ coating and $\mathrm{C} / \mathrm{C}$ composites, is needed to heat at 2173 $2373 \mathrm{~K}$ for $2-4 \mathrm{~h} \mathrm{[13]} \mathrm{[14]} \mathrm{[15]} \mathrm{[16].} \mathrm{Cracks} \mathrm{will} \mathrm{be} \mathrm{formed} \mathrm{inevitably} \mathrm{in} \mathrm{the}$ coatings due to the mismatch of thermal expansion between the coatings and the composites. CVD can prepare the coatings at a lower preparation temperature but need to be provided a very long preparation time [17] [18] [19]. The drawback of time-consumption also exists in slurry method [20] [21] [22]. In addition, double coatings are needed to be prepared by two-step methods [7]-[22].

In this paper, we use a one-step technique, spark plasma sintering (SPS), to prepare rapidly a double $\mathrm{SiC}$ coating on $\mathrm{C} / \mathrm{C}$ composites at $1350^{\circ} \mathrm{C}$ for $1 \mathrm{~min}$. To our knowledge, no literature has been published about using SPS technology to prepare muti-layer coatings on $\mathrm{C} / \mathrm{C}$ composites. The microstructures and oxidation resistant of double $\mathrm{SiC}$ coating on $\mathrm{C} / \mathrm{C}$ composites are investigated.

\section{Experimental Procedure}

C/C composites (Jiangnan Graphite Co., Ltd., Hunan, China) with a density of $1.70 \mathrm{~g} / \mathrm{cm}^{3}$ were used as substrates, which were cut into small cylinder specimens (Ф $20 \mathrm{~mm} \times 6 \mathrm{~mm}$ ). The substrates were hand-grinded with 400, 600 and 1000 grit $\mathrm{SiC}$ paper, sequentially. Then they were cleaned ultrasonically in ethanol and dried at $100^{\circ} \mathrm{C}$ for $1 \mathrm{~h}$.

Raw materials used for inner SiC coating were Si $(200$ mesh, Sinopharm Chemical Reagent Co., Ltd., Shanghai, China) and graphite (200 mesh, Jiangnan Graphite Co., Ltd., Hunan, China) powders. Considering volatilization of Si and high melting point of $\mathrm{SiC}$, the mole ratio of $\mathrm{Si}$ to $\mathrm{C}$ for inner coating was 1.11 and powders for outer $\mathrm{SiC}$ coating was composed of $90 \mathrm{wt} \% \beta$-SiC $(2.5 \mu \mathrm{m}$, 99.9\%, Enomaterial Co., Ltd, Qinhuangdao, China) and $10 \mathrm{wt} \% \mathrm{Si}$. Prior to SPS, the above powders were dried at $100^{\circ} \mathrm{C}$ for $2 \mathrm{~h}$ and well mixed in a ball mill for $24 \mathrm{~h}$. Then, as shown in Figure 1, C/C composite was placed into a cylindrical graphite die of $20 \mathrm{~mm}$ in diameter and covered with the powders for the inner and outer coating, sequentially. Sintering experiment was carried out using a spark plasma sintering system (SPS-3.20MK-IV) in a vacuum $\left(6 \times 10^{-3} \mathrm{~Pa}\right)$ atmosphere. The heating and cooling rate were controlled at $200^{\circ} \mathrm{C} / \mathrm{min}$. Temperature, holding time and pressure was set as $1350^{\circ} \mathrm{C}, 1 \mathrm{~min}$ and $30 \mathrm{MPa}$, respectively. For comparison, SiC-coated $\mathrm{C} / \mathrm{C}$ composites, that is $\mathrm{C} / \mathrm{C}$ composites only with a $\mathrm{SiC}$ inner coating, under the same preparation conditions were also pre- 


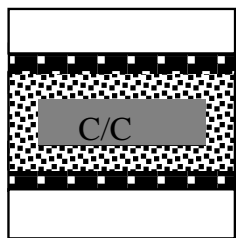

Outer coating powders

国 Inner coating powders

Punches

Figure 1. Schematic diagram of $\mathrm{SPS}$ for $\mathrm{SiC} / \mathrm{SiC}$ coated $\mathrm{C} / \mathrm{C}$ composites.

pared using $\mathrm{Si}$ and $\mathrm{C}$ powders. For comparison, C/C composites coated a single $\mathrm{SiC}$ layer with $\mathrm{Si}$ and graphic were prepared under the same conditions.

Surface and cross-section morphology of the coated composites were observed by scanning electron microscopy (SEM) using a KYKY2800 digital scanning electron microscope (Bejing, China). Crystalline structure of the coatings was measured by means of X-ray diffraction (XRD) using a D/Max-2500pc diffractometer (Japan) equipped with a standard $\mathrm{Cu}-\mathrm{Ka}$ radiation source employing a step size of $0.02^{\circ}$ in $2 \theta$.

Thermal behavior of double $\mathrm{SiC}$ coatings was analyzed using differential scanning calorimeter test and thermogravimetry (DSC-TG) complex thermal analysis with a NETZSCH differential scanning calorimeter (Model STA449C, Germany). The coatings were heated at $20^{\circ} \mathrm{C} / \mathrm{min}$ up to $1500^{\circ} \mathrm{C}$ in flowing air.

To study the protection effects of double $\mathrm{SiC}$ coatings, the coated samples were placed in a furnace and oxidized at $1600^{\circ} \mathrm{C}$ for different time with a heating rate of $10^{\circ} \mathrm{C} / \mathrm{min}$. The weight of the coated samples was measured before and after the oxidation test, and the weight changes rate was determined according to Equation (1):

$$
\Delta M=\frac{m_{f}-m_{i}}{m_{i}} \times 100
$$

where $m_{i}$ is the initial weight (before the oxidation test) and $m_{f}$ is the final weight (after the oxidation test). The morphologies and phase structures of the coated composites after the oxidation test were also examined by means of SEM and XRD, respectively.

\section{Results and Discussions}

The surface SEM image and XRD pattern of SiC inner coating are shown in Figure 2(a) and Figure 2(b), respectively. As shown in Figure 2(a), SiC inner coating is dense with many good crystalline particles ranged from 3 to $6 \mu \mathrm{m}$. No visible holes and cracks are found in the coating. Moreover, as shown in Figure 2 (b), only $\beta$-SiC could be detected in the inner coating, indicating that $\mathrm{Si}$ and $\mathrm{C}$ have reacted with each other at $1350^{\circ} \mathrm{C}$ to form a $\mathrm{SiC}$ coating on the substrate. In addition, no Si and $\mathrm{C}$ are detected, meaning that they have been consumed completely during SPS.

The surface SEM image and XRD pattern of $\mathrm{SiC}$ outer coating are shown in Figure 3(a) and Figure 3(b), respectively. The coating is dense and crack-free. From Figure 3(b), it can be found that the coating is composed of $\beta$-SiC and a 


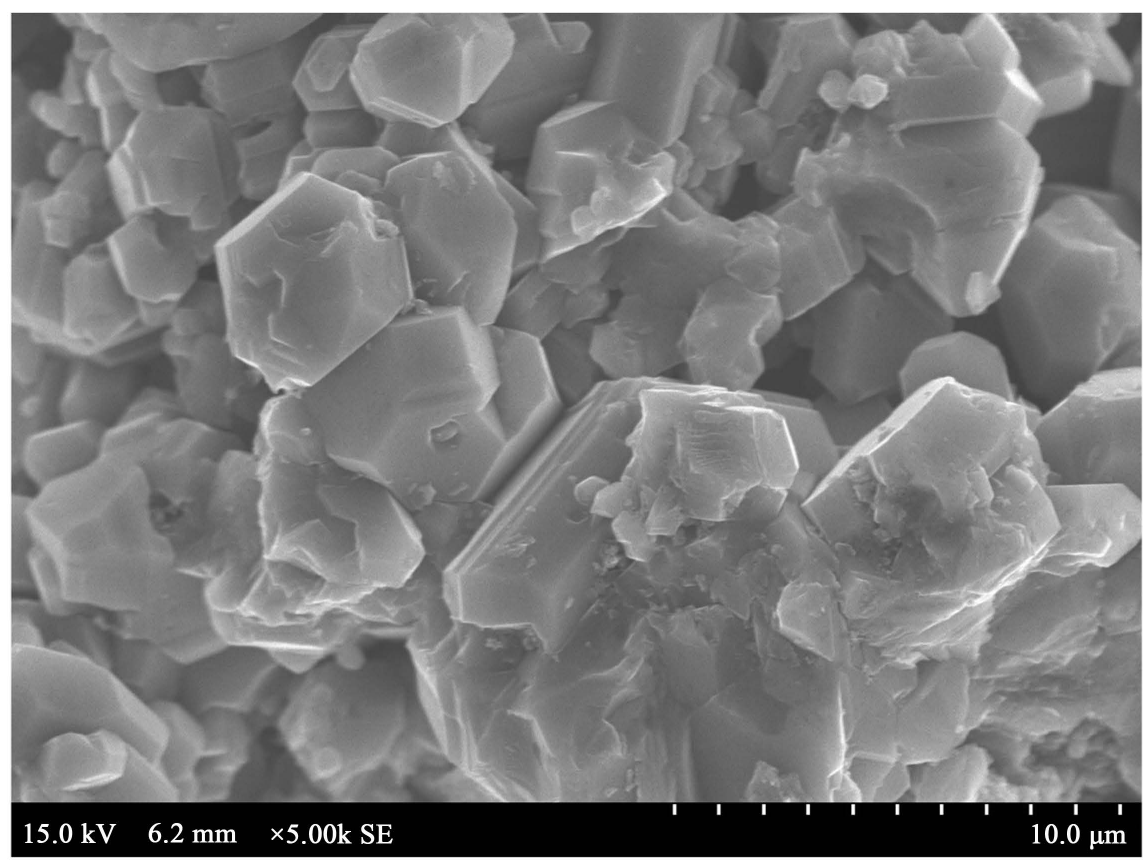

(a)

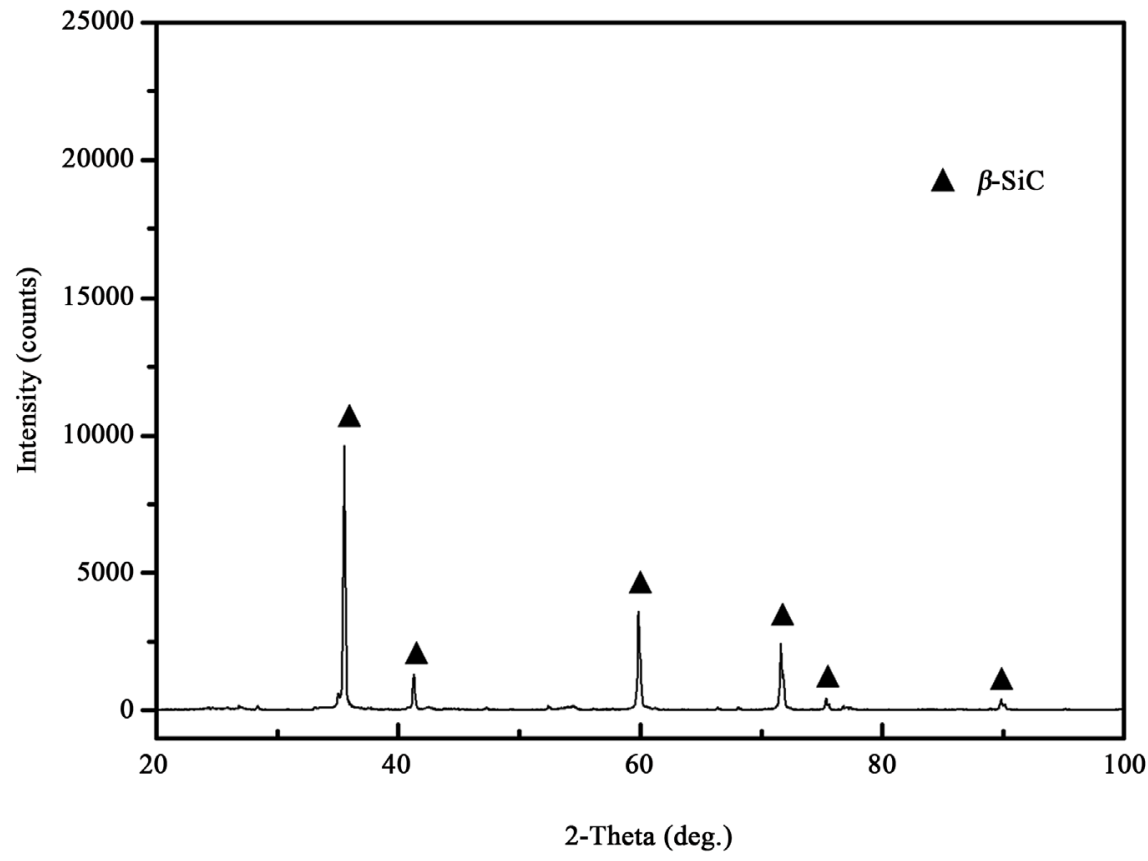

(b)

Figure 2. SEM image (a) and XRD pattern (b) of $\mathrm{SiC}$ inner coating prepared at $1350^{\circ} \mathrm{C}$ for $1 \mathrm{~min}$.

small quantity of Si. The size of the particles in the coating is found to be less than $2 \mu \mathrm{m}$, which indicates that original SiC particles remain, and while large $\mathrm{Si}$ particles have melted. The liquid Si could fill in the gaps among SiC particles and act as a binder to bond $\mathrm{SiC}$ particles together, which is advantageous to form a dense coating and inhibit oxygen diffusion inwards $\mathrm{C} / \mathrm{C}$ composite. 


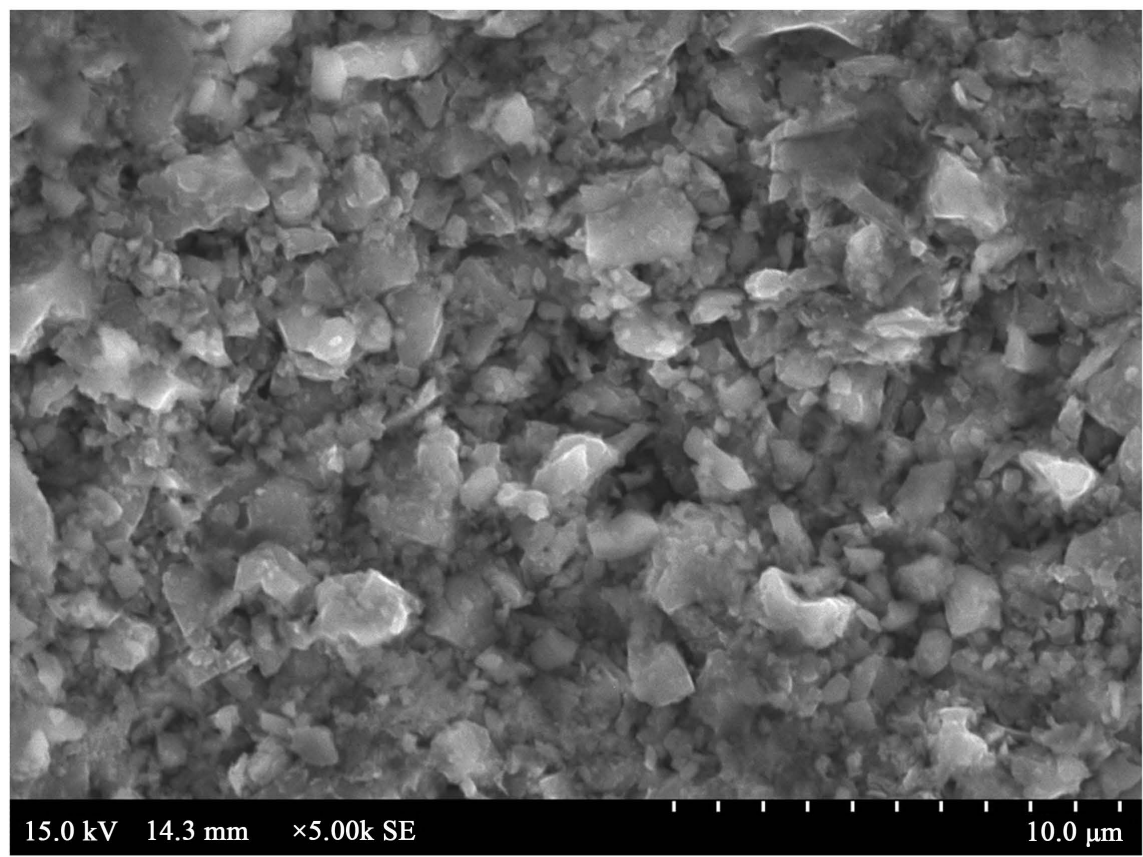

(a)

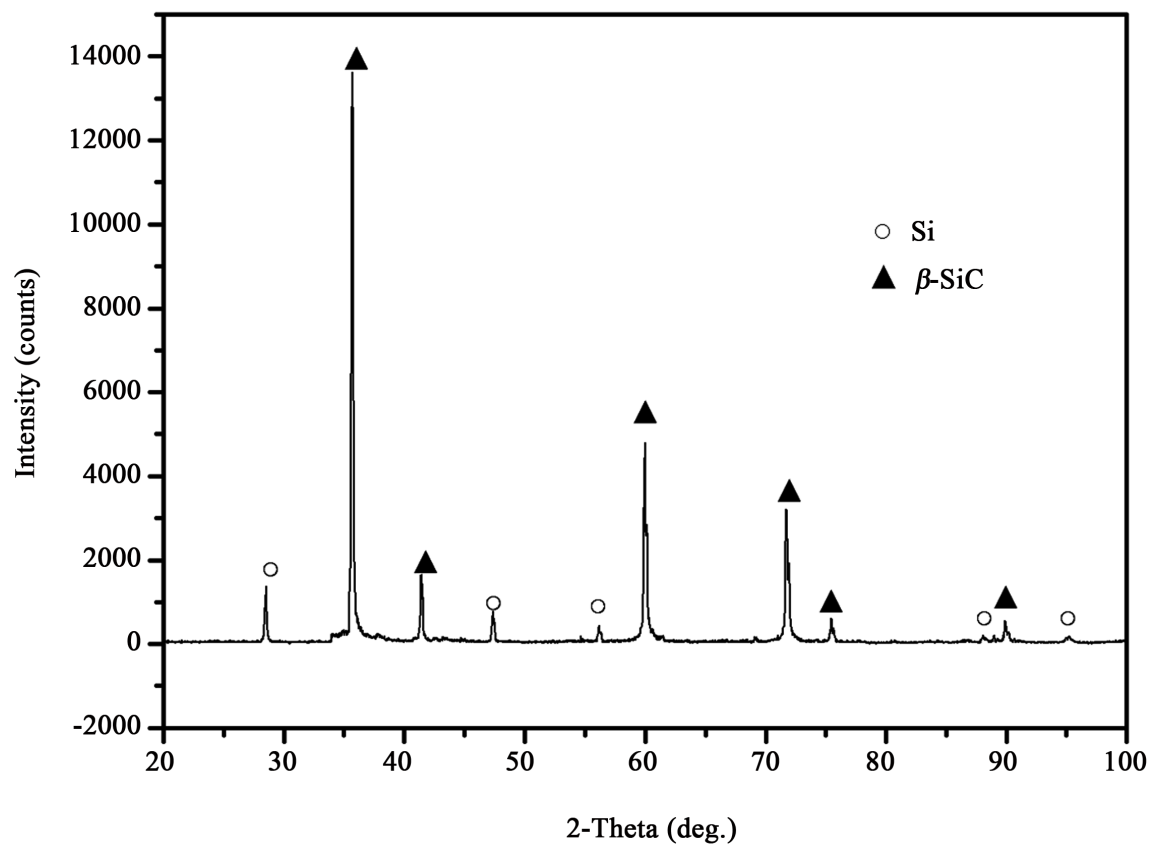

(b)

Figure 3. SEM image (a) and XRD pattern (b) of $\mathrm{SiC}$ outer coating prepared at $1350^{\circ} \mathrm{C}$ for $1 \mathrm{~min}$.

Cross-section images of $\mathrm{SiC} / \mathrm{SiC}$ coated composite are shown in Figure 4. A good adhesion between the inner coating and the substrate is found due to reaction between Si powder and C/C substrate. The outer coating is well bonded with the inner coating due to no thermal mismatch between them, as shown in Figure 4(b). 


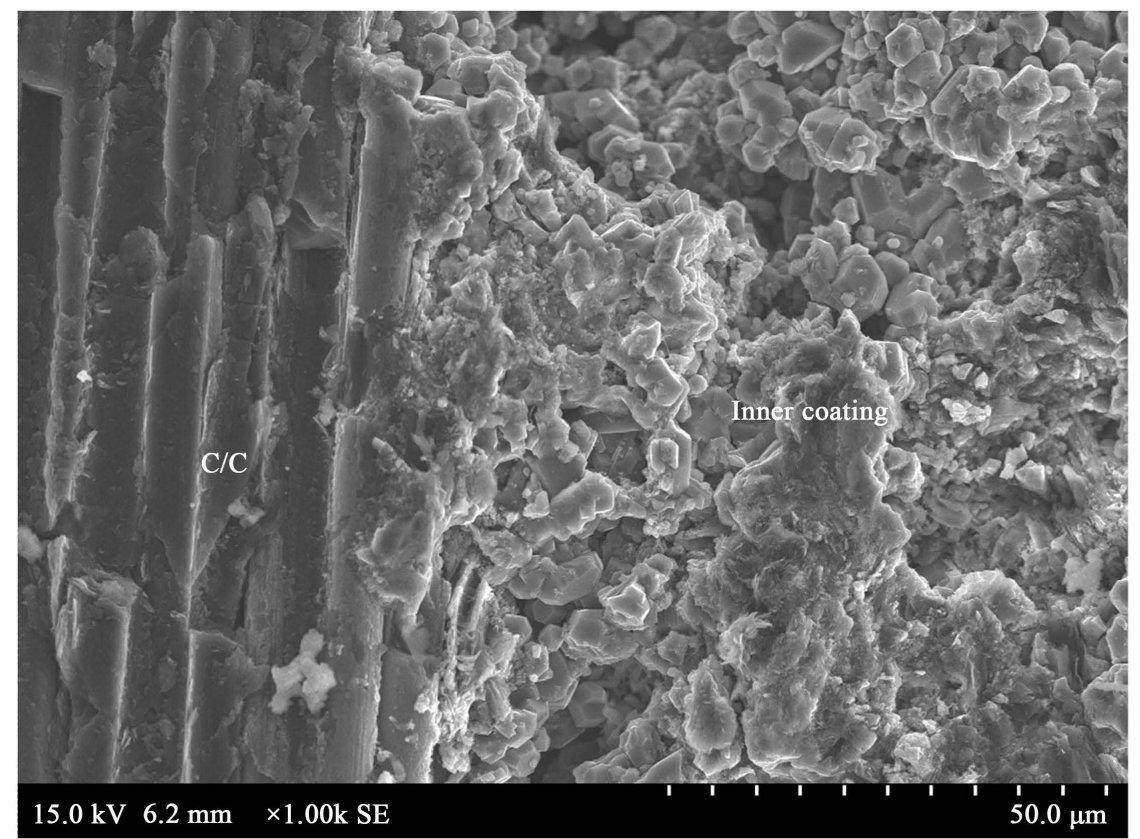

(a)

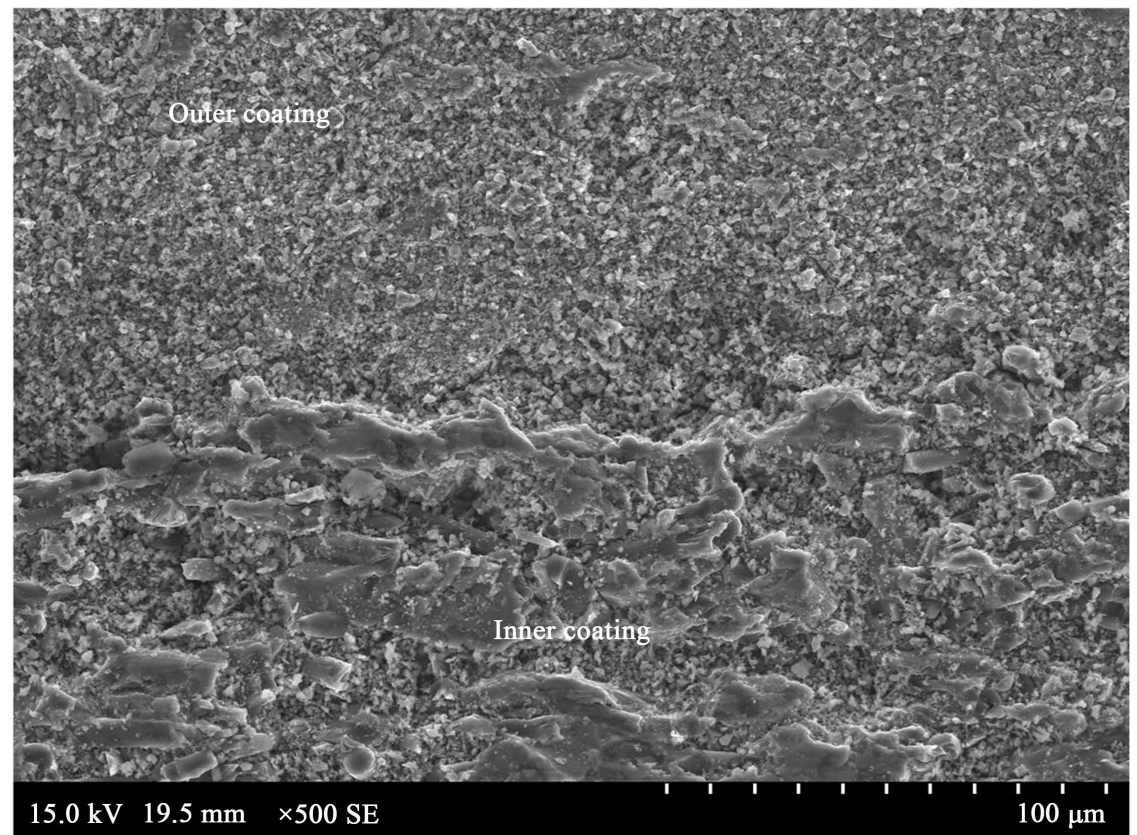

(b)

Figure 4. Cross-section SEM images of double SiC coating prepared at $1350^{\circ} \mathrm{C}$ for $1 \mathrm{~min}$ : (a) between inner coating and substrate (b) between outer and inner coating.

The thermal behavior of the $\mathrm{SiC} / \mathrm{SiC}$ coating under air has been measured by TG-DSC. The corresponding TG-DSC curves are shown in Figure 5(a) and Figure 5(b), respectively. A gradual weight gain is observed on heating to $1181^{\circ} \mathrm{C}$ due to the ambient $\mathrm{SiO}_{2}$ layer on the surface of $\mathrm{SiC} / \mathrm{Si}$, which reduces the oxidation rate of $\mathrm{SiC} / \mathrm{Si}$ to a very low speed. Above this temperature, the diffusion rate of oxygen from air to $\mathrm{SiC} / \mathrm{Si}$ promotes and an obvious weight gain is 


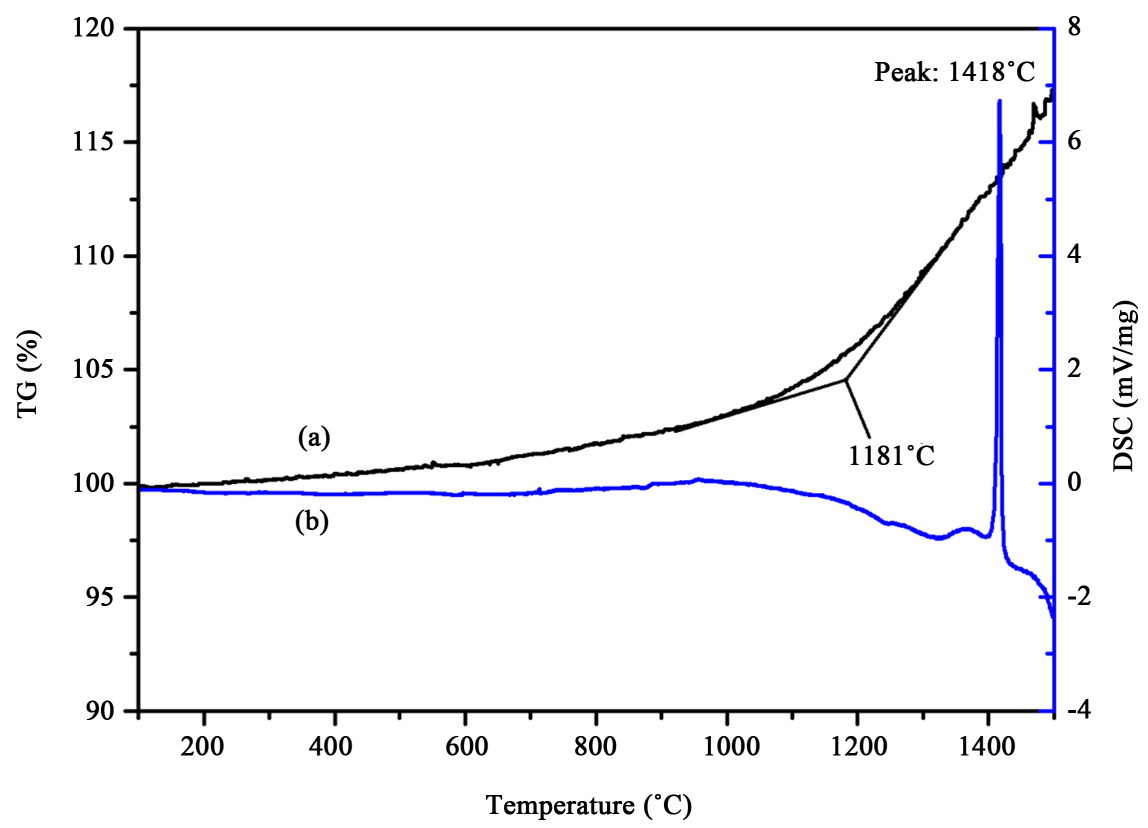

Figure 5. TG-DSC curves of double SiC coating prepared by SPS at $1350^{\circ} \mathrm{C}$ for $1 \mathrm{~min}$ : (a) TG; (b) DSC.

obtained due to the oxidation of $\mathrm{SiC} / \mathrm{Si}$. There is an endothermic reaction occurring at approximately $1418^{\circ} \mathrm{C}$ in DSC curve. This endothermic effect is attributed to the melt of $\mathrm{Si}$ powder in $\mathrm{SiC}$ outer coating. Around $1500^{\circ} \mathrm{C}$, double $\mathrm{SiC}$ coating has a residual mass of $117.6 \mathrm{wt} \%$.

Figure 6 shows oxidation curves of the coated C/C composite at $1600^{\circ} \mathrm{C}$ in air. It can be seen that from Figure 6(a) that the weight of $\mathrm{SiC}$ coated $\mathrm{C} / \mathrm{C}$ composites loses rapidly with oxidation time and reaches up to $-8.0 \mathrm{wt} \%$ after oxidation only for $36 \mathrm{~h}$, which indicates that $\mathrm{SiC}$ inner coating cannot protect $\mathrm{C} / \mathrm{C}$ composites from oxidation effectively. As shown in Figure 6(b), SiC/SiC coating can effectively protect the substrate from oxidation and the oxidation process of $\mathrm{SiC} / \mathrm{SiC}$ coated $\mathrm{C} / \mathrm{C}$ composites can be divided into three stages. At the first $24 \mathrm{~h}$, weight gains slowly due to the formation of $\mathrm{SiO}_{2}$ phase and the low oxygen permeation constant. With the oxidation time increased, from $24 \mathrm{~h}$ to $72 \mathrm{~h}$, weight change versus time stars to exhibit the trend of weight loss and the weight loss of $2.54 \%$ is detected after oxidation for $72 \mathrm{~h}$, suggesting oxygen has passed through the double coating and eroded the substrate. Above $72 \mathrm{~h}$, weight loses is almost constant, suggesting that oxidation enters a steady state, indicating the tunnel of oxygen diffusion has remedied by the vitreous $\mathrm{SiO}_{2}$ glass. When oxidation for $120 \mathrm{~h}$, the weight loss of the double $\mathrm{SiC}$ coated composite is only $2.62 \%$.

Figure 7 shows the SEM images of the coated composites after oxidation at $1600^{\circ} \mathrm{C}$ in air for different time. For $\mathrm{SiC}$ coated $\mathrm{C} / \mathrm{C}$ composite, when oxidation at $1600^{\circ} \mathrm{C}$ for $36 \mathrm{~h}$, as shown in Figure $7(\mathrm{a})$, the particles are invisible and covered by vitreous $\mathrm{SiO}_{2}$ due to the oxidation of $\mathrm{SiC}$. So the coating surface becomes smoother and denser. However, vitreous $\mathrm{SiO}_{2}$ is not in sufficient quantities to seal cracks. Therefore, a long and deep crack is found in SiC coating due to 


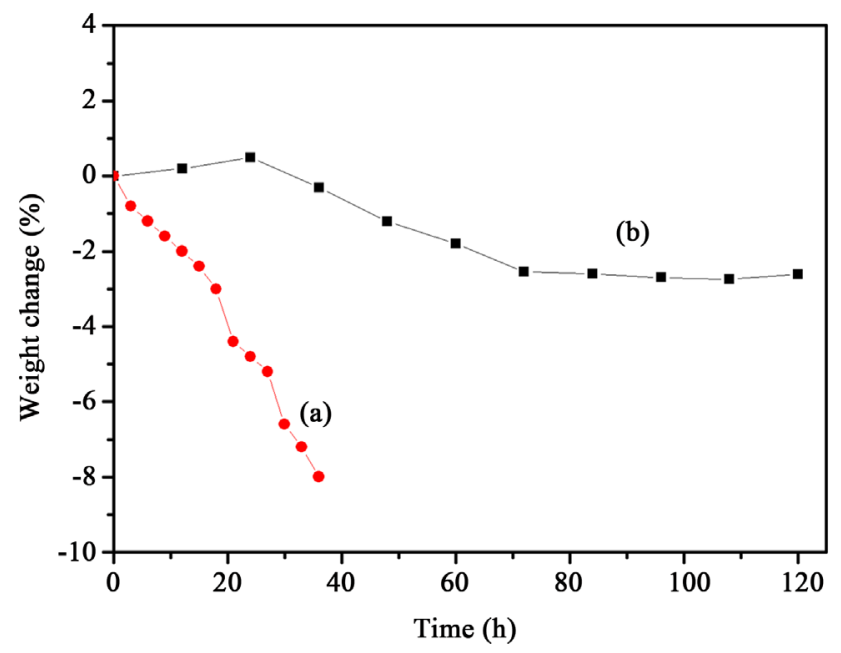

Figure 6. Oxidation curves of (a) $\mathrm{SiC}$ and (b) $\mathrm{SiC} / \mathrm{SiC}$ coated $\mathrm{C} / \mathrm{C}$ composite at $1600^{\circ} \mathrm{C}$ in air.

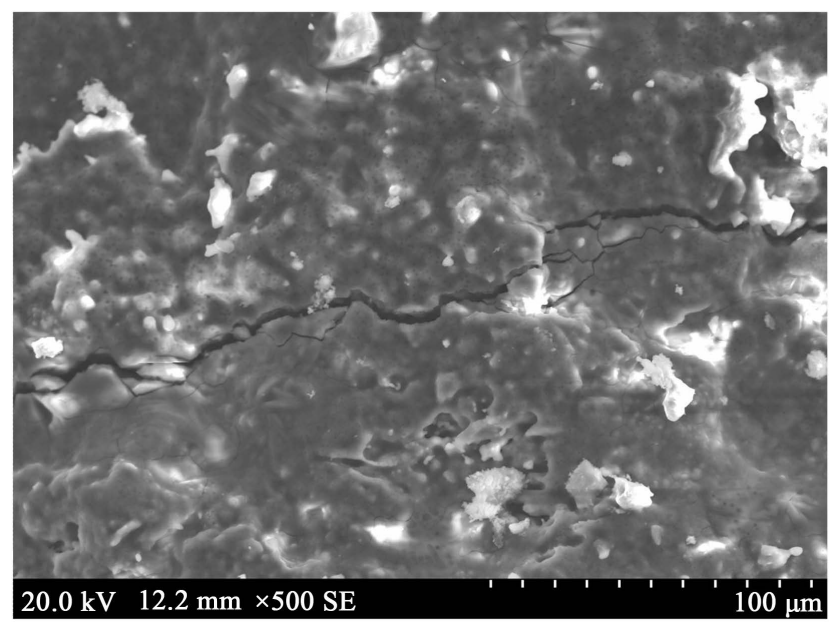

(a)

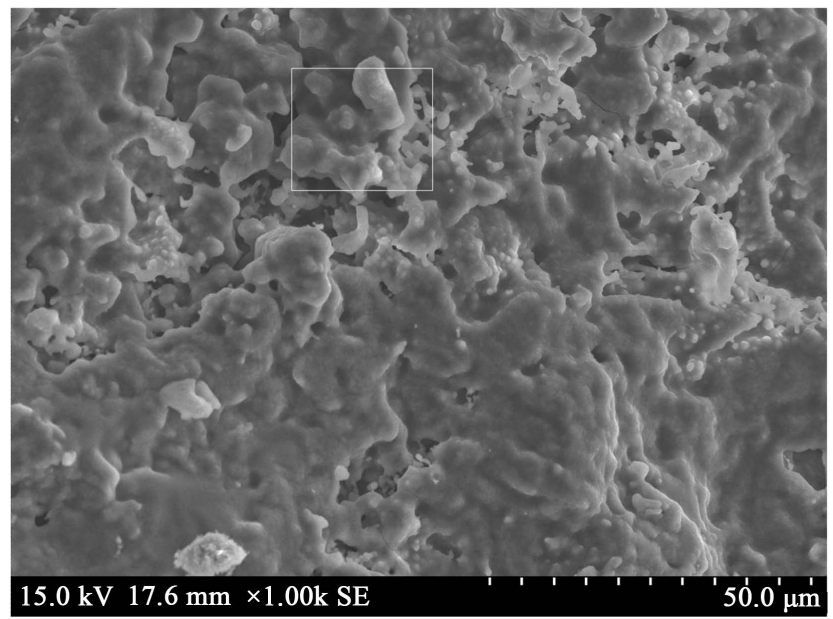

(c)

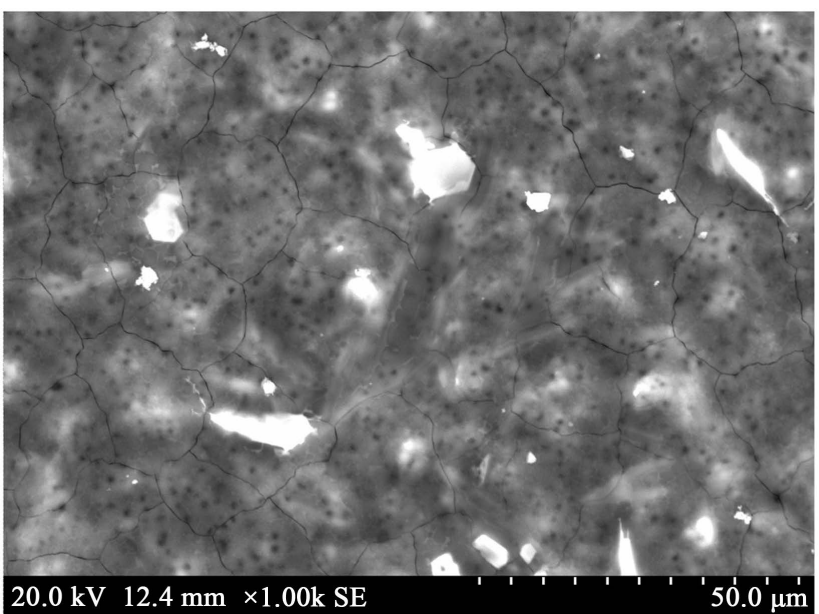

(b)

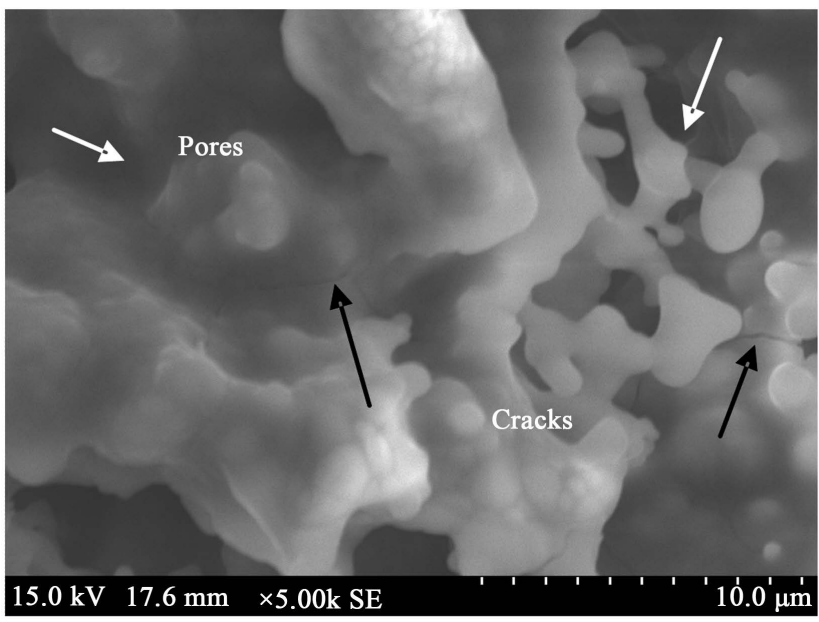

(d)

Figure 7. SEM images of (a) SiC- and (b)-(d) SiC/SiC-coated composites after oxidation at $1600^{\circ} \mathrm{C}$ in air for different time: (a) 36 h; (b) $72 \mathrm{~h}$; (c) $120 \mathrm{~h}$; (d) magnification of (b). 
thermal expansion mismatch between $\mathrm{SiC}$ coating and the substrate, through which oxygen would diffuse into the substrate directly and cause severe oxidation. This is in good agreement with the result of Figure 6(a) and well explained why the protection of $\mathrm{SiC}$ coating was not desirable. For $\mathrm{SiC} / \mathrm{SiC}$ coated $\mathrm{C} / \mathrm{C}$ composite, when oxidation for $72 \mathrm{~h}$, large amounts of fluid is formed because of the melted $\mathrm{Si}$ and the oxidation of $\mathrm{SiC}$ and $\mathrm{Si}$, so the coating surface became much denser and smoother and the cracks are healed into narrow and shallow ones, which had little effect on the oxidation resistance of the coating, as shown in Figure 6(b). After oxidation at $1600^{\circ} \mathrm{C}$ for $120 \mathrm{~h}$, as shown in Figure $7(\mathrm{c})$ and Figure $7(\mathrm{~d})$, the cracks are less and invisible resulting in a steady anti-oxidation ability of double $\mathrm{SiC}$ coating. It is worth mentioning that the coating surface become microscopically very rough due to volatilization of $\mathrm{SiO}_{2}$. The pores formed by the gas resultant remained in the coating, which greatly are disadvantageous to the oxidation resistance of the coating.

Figure 8 shows the XRD patterns of $\mathrm{SiC} / \mathrm{SiC}$ coated composites after oxidation at $1600^{\circ} \mathrm{C}$ in air for different time. After oxidation at $1600^{\circ} \mathrm{C}$ for $24 \mathrm{~h}$, the diffraction peaks are $\beta$-SiC, $\mathrm{Si}$ and $\mathrm{SiO}_{2}$. After oxidation at $1600^{\circ} \mathrm{C}$ for $72 \mathrm{~h}$, the diffraction peaks of $\mathrm{Si}$ disappeared and the intensity of $\mathrm{SiO}_{2}$ peaks become stronger due to the oxidation of Si. With the increase of oxidation time, the intensity of $\mathrm{SiO}_{2}$ peaks becomes stronger and stronger, while the intensity of $\mathrm{SiC}$ peaks gets weaker and weaker due to the oxidation of $\mathrm{SiC}$. However, after oxidation at $1600^{\circ} \mathrm{C}$ for $120 \mathrm{~h}$, the intensity of $\mathrm{SiC}$ peaks is still strong, which indicates that the failures of the coating are mainly caused by cracks and oxygen diffusion.

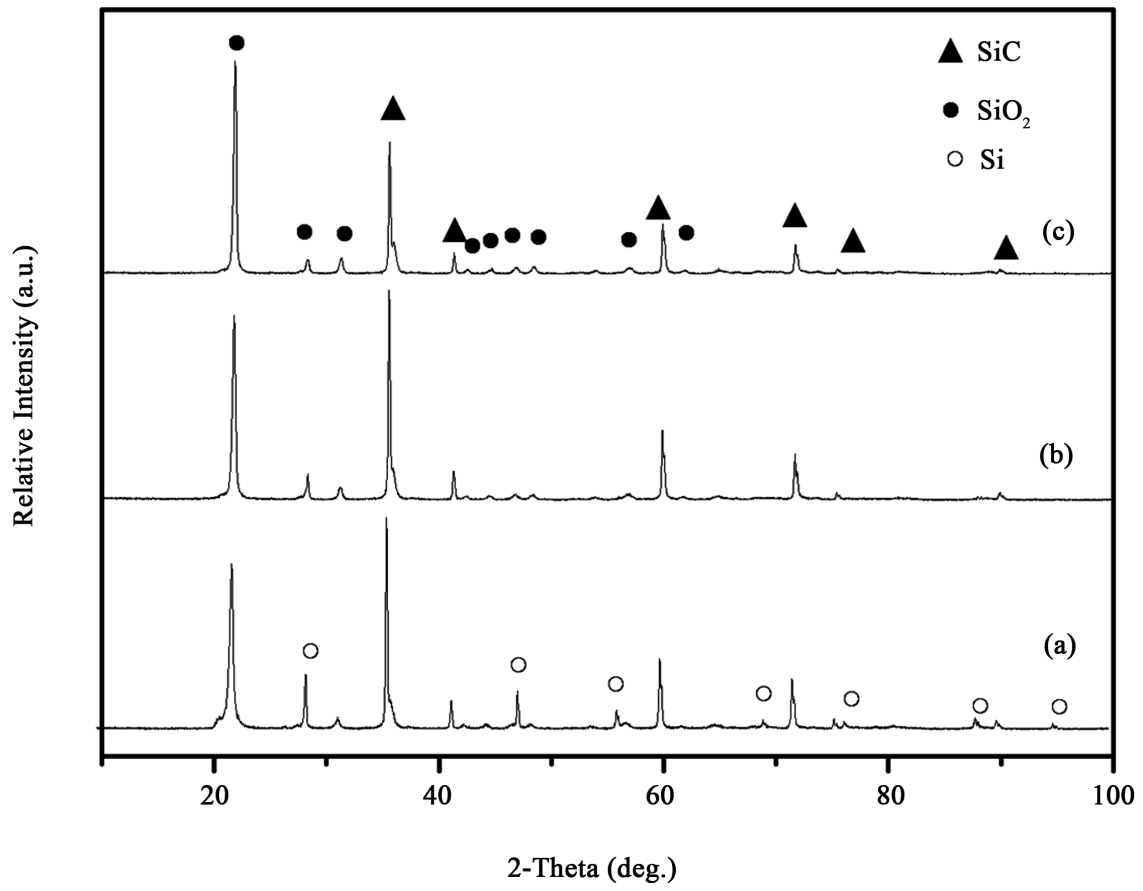

Figure 8. XRD pattern of the coated sample after oxidation at $1600^{\circ} \mathrm{C}$ for different time: (a) $24 \mathrm{~h}$; (b) $72 \mathrm{~h}$; (c) $120 \mathrm{~h}$. 


\section{Conclusions}

1) SPS is a promising method to prepare double $\mathrm{SiC}$ coatings on $\mathrm{C} / \mathrm{C}$ composites. The double $\mathrm{SiC}$ coating could be obtained by SPS at $1350^{\circ} \mathrm{C}$ for $1 \mathrm{~min}$.

2) The double coating is very dense and crack-free, composed of $\beta$-SiC and Si, and has a good bonding with the substrate.

3) The double $\mathrm{SiC}$ coating has good oxidation resistance and can protect $\mathrm{C} / \mathrm{C}$ composites against oxidation at $1600^{\circ} \mathrm{C}$ for $120 \mathrm{~h}$ with a weight loss of $2.62 \%$. The failures of the coating are mainly caused by cracks and oxygen diffusion.

\section{Acknowledgements}

This work was supported by the Opening Project of Key Laboratory of Inorganic coating materials, Chinese Academy of Sciences, under grant No. KLICM-2014-06.

\section{References}

[1] Bacos, M.P. (1993) Carbon-Carbon Composites: Oxidation Behavior and Coatings Protection. Journal De Physique IV, 3, 1895-1899. https://doi.org/10.1051/jp4:19937303

[2] Ren, J., Zhang, Y., Hu, H., Zhang, P., Fei, T. and Zhang, L. (2016) HfC Nanowires to Improve the Toughness and Oxidation Resistance of Si-Mo-Cr/SiC Coating for $\mathrm{C} / \mathrm{C}$ Composites. Ceramics International, 42, 14518-14525. https://doi.org/10.1016/j.ceramint.2016.06.064

[3] Zhang, Y.L., Huang, J.F., Zhu, K.J., Cao, L.Y., Li, C.Y., Zhou, L., Zhang, B.Y., Kong, W.H. and Zhang, B. (2015) Effects of Voltage on Microstructure and Oxidation Resistance of $\mathrm{SiB}_{6}-\mathrm{MoSi}_{2}$ Coating Deposited by Pulse Arc Discharge Deposition. Applied Surface Science, 304, 43-48. https://doi.org/10.1016/j.apsusc.2015.03.003

[4] Fu, Q.G., Xue, H., Wu, H., Li, H.J., Li, K.Z. and Tao, J. (2010) A Hot-Pressing Reaction Technique for SiC Coating of Carbon/Carbon Composites. Ceramics International, 36, 1463-1466. https://doi.org/10.1016/j.ceramint.2010.01.002

[5] Hao, W., Huang, J.F., Cao, L.Y., Yin, L.X., Wu, J.P., Fei, J., Huang, Y.C. and Yang, L.Q. (2013) An $\mathrm{AlPO}_{4}-\mathrm{SiC}-\mathrm{MoSi}_{2} / \mathrm{SiC}$ Oxidation Protective Coating on Carbon/Carbon Composites by Pulse Arc Discharge Deposition. Ceramics International, 39, 9797-9801. https://doi.org/10.1016/j.ceramint.2013.05.052

[6] Chen, Z., Li, H., Li, K., Shen, Q. and Fu, Q. (2014) Influence of Grain Size on Wear Behavior of SiC Coating for Carbon/Carbon Composites at Elevated Temperatures. Materials \& Design, 53, 412-418. https://doi.org/10.1016/j.matdes.2013.07.046

[7] Sun, C., Li, H., Fu, Q., Zhang, J. and Peng, H. (2013) Double SiC Coating on Carbon/Carbon Composites against Oxidation by a Two-Step Method. Transactions of Nonferrous Metals Society of China, 23, 2107-2112. https://doi.org/10.1016/S1003-6326(13)62703-X

[8] Yang, X., Huang, Q., Su, Z., Chai, L., Wang, X. and Zhou, L. (2013) A Double Layer Nanostructure SiC Coating for Anti-Oxidation Protection of Carbon/Carbon Composites Prepared by Chemical Vapor Reaction and Chemical Vapor Deposition. Ceramics International, 39, 3053-3062.

https://doi.org/10.1016/j.ceramint.2012.11.104

[9] Ma, C., Li, H., Wu, H., Fu, Q., Sun, C., Shi, X., Zhang, Y., Zhang, Z., Tao, J. and Han, Z. (2013) Mullite Oxidation Resistant Coating for SiC-Coated Carbon/Carbon Composites by Supersonic Plasma Spraying. Journal of Materials Science and 
Technology, 29, 29-33. https://doi.org/10.1016/j.jmst.2012.11.001

[10] Wang, K.T., Cao, L.Y., Huang, J.F. and Fei, J. (2013) A Mullite/SiC Oxidation Protective Coating for Carbon/Carbon Composites. Journal of the European Ceramic Society, 33, 191-198. https://doi.org/10.1016/j.jeurceramsoc.2012.08.009

[11] Shin, X.H., Ren, Y.C., Li, H.J., Li, T., Zhang, X., Huo, J.H. and Hu, X.J. (2014) $\mathrm{LaB}_{6}$ Modified $\mathrm{MoSi}_{2}$ Ceramic Coating of SiC Coated Carbon/Carbon Composites for Oxidation Resistance at High Temperature. Ceramics International, 40, 6355-6358. https://doi.org/10.1016/j.ceramint.2013.10.155

[12] Hao, W., Huang, J., Cao, L., Yin, L., Ouyang, H., Yang, L., Fei, J. and Zhang, Y. (2014) Oxidation Protective $\mathrm{AlPO}_{4}$ Coating for SiC Coated Carbon/Carbon Composites for Application at $1773 \mathrm{~K}$ and $1873 \mathrm{~K}$. Journal of Alloys and Compounds, 589, 153-156.

[13] Yao, X., Li, H., Zhang, Y. and Wang, Y. (2014) Oxidation and Mechanical Properties of $\mathrm{SiC} / \mathrm{SiC}-\mathrm{MoSi}_{2}-\mathrm{ZrB}_{2}$ Coating for Carbon/Carbon Composites. Journal of Materials Science and Technology, 30, 123-127. https://doi.org/10.1016/j.ceramint.2013.10.155

[14] Ren, X., Lin, H., Chu, Y., Li, K. and Fun, Q. (2014) $\mathrm{ZrB}_{2}-\mathrm{SiC}$ Gradient Oxidation Protective Coating for Carbon/Carbon Composites. Ceramics International, 40, 7171-7176. https://doi.org/10.1016/j.ceramint.2013.12.055

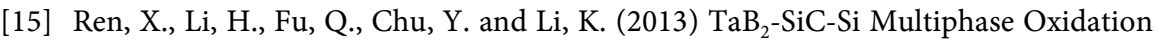
Protective Coating for SiC-Coated Carbon/Carbon Composites. Journal of the $\mathrm{Eu}$ ropean Ceramic Society, 33, 2953-2959. https://doi.org/10.1016/j.jeurceramsoc.2013.06.028

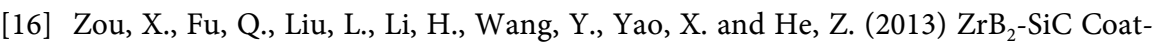
ing to Protect Carbon/Carbon Composites against Ablation. Surface and Coatings Technology, 226, 17-21. https://doi.org/10.1016/j.surfcoat.2013.03.027

[17] Long, Y., Javed, A., Shapiro, I., Chen, Z., Xiong, X. and Xiao, P. (2011) The Effect of Substrate Position on the Microstructure and Mechanical Properties of SiC Coatings on Carbon/Carbon Composites. Surface and Coatings Technology, 206, 568-574. https://doi.org/10.1016/j.surfcoat.2011.07.087

[18] Zheng, G.B., Sano, H. and Uchiyama, Y. (2011) A Carbon Nanotube Enhanced SiC Coating for the Oxidation Protection of C/C Composite Materials. Composites Part $B, 42,2158-2162$. https://doi.org/10.1016/j.compositesb.2011.05.012

[19] Wang, Y., Xiong, X., Li, G., Zhang, H., Chen, Z., Sun, W. and Zhao, X. (2012) Microstructure and Ablation Behavior of Hafnium Carbide Coating for Carbon/Carbon Composites. Surface and Coatings Technology, 206, 2825-2832.

https://doi.org/10.1016/j.surfcoat.2011.12.001

[20] Zhang, Y.L., Li, H.J., Hu, Z.X., Ren, J.C. and Li, K.Z. (2013) Microstructure and Oxidation Resistance of Si-Mo-B Coating for C/SiC Coated Carbon/Carbon Composites. Corrosion Science, 72, 150-155. https://doi.org/10.1016/j.corsci.2013.03.015

[21] Zhang, Y., Li, H., Hu, Z., Li, K. and Zhang, L. (2013) C/SiC/MoSi 2 -SiC-Si Multilayer Coating for Oxidation Protection of Carbon/Carbon Composites. Transactions of Nonferrous Metals Society of China, 23, 2118-2122. https://doi.org/10.1016/S1003-6326(13)62705-3

[22] Zhang, Y.L., Li, H.J., Yao, X.Y., Li, K.Z. and Qiang, X.F. (2011) Oxidation Protection of $\mathrm{C} / \mathrm{SiC}$ Coated Carbon/Carbon Composites with Si-Mo Coating at High Temperature. Corrosion Science, 53, 2075-2079. https://doi.org/10.1016/j.corsci.2011.02.024 